\title{
連続鋳造モールド内浸漬ノズル近傍でのモールドパウ ダー巻き込みに及ぼす浸漬ノズルの濡れ性の影響
}

\author{
吉田 仁 ${ }^{*} \cdot$ 井口 学 ${ }^{* 2} \cdot$ 横谷 真一郎*3 \\ Effect of Wettability of Immersion Nozzle on Mold Powder Entrapment \\ around Immersion Nozzle in Continuous Casting Mold
}

Jin YoshIDA, Manabu IGUCHI and Shin-ichiro YoKoYA

Synopsis : Mold powder entrapment in a continuous casting mold is harmful for producing clean steel. As the immersion nozzle is poorly wetted by molten steel in the real processes, the effect of the surface wettability of the nozzle on the descent of mold powder due to pressure difference along the nozzle was investigated in this model study. Concerning a poorly wetted immersion nozzle, mold powder descended most deeply on the surface of the nozzle, while for a highly wetted immersion nozzle the deepest mold powder-molten steel interface appeared at a position away from the nozzle. The poorly wetted immersion nozzle promoted the descent of mold powder significantly compared with the highly wetted immersion nozzle. Accordingly, the mold powder would be more entrapped at the ports of the poorly wetted nozzle. An empirical equation was proposed for the descent of the mold powder.

Key words: continuous casting; slab caster; mold powder entrapment; immersion nozzle; particle imaging velocimetry; water model; wettability.

\section{1. 緒言}

鋼の連続鋳造において，湯面上に存在するモールドパウ ダーは，湯面の保温，溶鋼の酸化防止，鋳型と溶鋼間の潤 滑等の役割を果たしている。しかし，モールドパウダーは 様々な要因により溶鋼中に巻き込まれて鋳片中で非金属介 在物として存在し，製品の欠陥となる。実機で巻き込み現 象を調査することは非常に困難であることから，多くの研 究者は水モデル実験を行っている。これまでに水モデル実 験に基づいて提案された巻き込み原因をまとめると Fig. 1 に模式的に示すようになる。

（1）溶鋼の反転流とパウダー層間でのせん断流による定 常削り込み ${ }^{1-7)}$

（2）急激な流れの変化が原因のせん断流による非定常巻 き込み ${ }^{8)}$

（3）溶鋼の片流机により浸漬ノズル周辺で発生するカル マン渦による巻き込み ${ }^{2,3,5,7,9-12)}$

（4）浸漬ノズル出口から上昇してきたアルゴンガス気泡 の崩壊による巻き込み ${ }^{13-16)}$

（5）溶鋼流が一定速度で浸漬ノズルを急に横切ったと き，ノズル背面で圧力が減少して発生する巻き込 み ${ }^{17)}$

上記の巻き込み原因のうち (1) ( 3), ( 5 ) はメニスカス における溶鋼流に片流れが生じたときに発生する。片流れ
はおもにアルミナ $\left(\mathrm{Al}_{2} \mathrm{O}_{3}\right)$ が二つある吐出孔の片側により 多く付着して流動抵抗を增加させることによって生じる。 また，浸漬ノズルと溶鋼の濡れ性は悪いために，アルミナ $\left(\mathrm{Al}_{2} \mathrm{O}_{3}\right)$ のノズル内壁への付着を防ぐために導入されてい るアルゴンガスがノズル内壁ではカーテン状に付着す

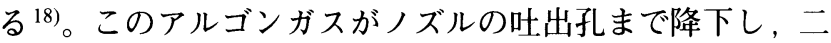
つある吐出孔の片側から流出して，モールド内を大きな気 泡となって上昇するとき，反対側の吐出孔からの溶鋼流が 増加して片流れが発生する。この気泡はノズル近傍の湯面 に衝突して Fig. 1-(4) に示す巻き込みが発生する。このよ うに，溶鋼の片流れとモールドパウダーの巻き込みは深く 関与している ${ }^{14)}$

そこで，鋳型内の溶鋼の流動状態を検知し，移動磁場

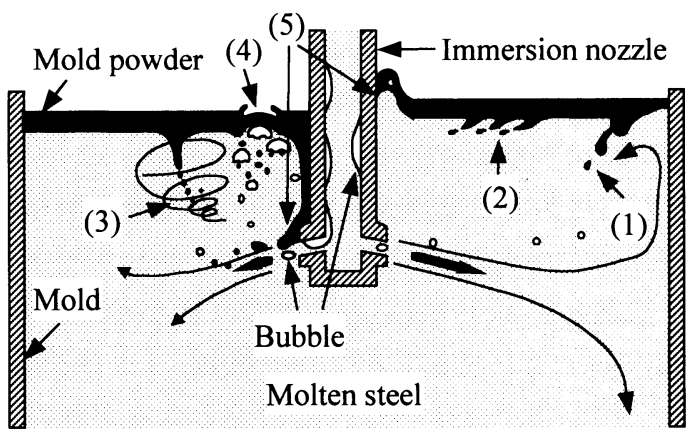

Fig. 1. Schematic illustration of mold powder entrapment.

平成 13年6月11日受付 平成 13年8月29日受理 (Received on June 11, 2001; Accepted on Aug. 29, 2001)

* 北海道大学大学院生 (Graduate Student, Hokkaido University)

* 2 北海道大学大学院工学研究科 (Graduate School of Engineering, Hokkaido University, North 13 West 8 Kita-ku Sapporo 060-8628)

*3 日本工業大学 (Nippon Institute of Technology) 
によりメニスカス溶鋼流速を適正な範囲に制御してモー ルドパウダーの巻き込みを抑制する技術が開発されてき

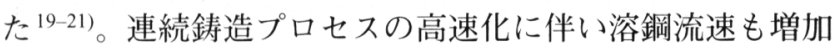
することから，モールドパウダー巻き込みメカニズムの解 明と溶鋼流の制御技術の開発はますますその重要性を増し ている。

前報 ${ }^{17)}$ において，著者らはFig. 1-(5) に示す浸漬ノズル 周辺での圧力差に起因する新たな巻き込みメカニズムを見 出し, それがモールドパウダー巻き込みの最も重要な原因 となりうることを示唆した。この巻き込みについてもう少 し詳しく述べておく。もし浸漬ノズルの二つの吐出孔から 溶鋼が均等に吐出し，短辺側で反転して浸漬ノズルへ近 寄って来るならば浸漬ノズル左右の表面の圧力は等しい。 ところが上記理由によって溶鋼の片流れが急に生じると， 浸漬ノズルへは流量の多い側からの溶鋼流が急にやって来 て，通り過ぎることになる。このような非定常な流れに よって，浸漬ノズルの左右の表面には，浸漬ノズルが定常 流の中におかれた場合に比べて非常に大きな圧力差が生 じ，この圧力差が駆動力となってモールドパウダーはノズ ル表面に沿って降下する。もしモールドパウダーが吐出孔 まで降下すれば溶鋼流により細かく分断されて巻き込まれ ることになる。このメカニズムによってのみ鋳片中に存在 する微細な非金属介在物 ${ }^{22)}$ を十分に説明できる。

実機において浸漬ノズルと溶鋼との濡れ性は一般に悪い が，前報 ${ }^{17)}$ の水モデル実験に扎いては，浸漬ノズルのモ デルとしてアルミニウム製円柱を用いたために，溶鋼のモ デルである食塩水との接触角は $60 \mathrm{deg}$. となり，濡れ性を 悪くすることができなかった。本研究では，浸漬ノズルの 濡れ性がモールドパウダーの巻き込みに及ぼす影響につい て調べた。

\section{2. 浸漬ノズルの濡れ性}

\section{$2 \cdot 1$ 圧力差によるノズル周りの流れがない場合}

実機では， $\mathrm{Al}_{2} \mathrm{O}_{3}$-グラファイト系の浸漬ノズルが広く 用いられている。鋳型内において $\mathrm{Al}_{2} \mathrm{O}_{3}$ はモールドパウ ダー中に溶解し，グラファイトは溶鋼中に溶解するため に，モールドパウダーはノズル表面のグラファイトリッチ 層と接触しており, 溶鋼は $\mathrm{Al}_{2} \mathrm{O}_{3}$ リッチ層と接触している (Fig. 2(a))。このとき，モールドパウダーとグラファイト および溶鋼とアルミナ $\left(\mathrm{Al}_{2} \mathrm{O}_{3}\right)$ は濡れ性が悪い。そこで， Fig. 2(a)ではともにPoor と記した。なお， $\mathrm{Al}_{2} \mathrm{O}_{3}$ と溶鋼に関 しては，接触角が $134 \sim 157 \mathrm{deg}$. であることが報告されて いる ${ }^{23)}$ 。

近年，向井らのグループにより，浸漬ノズルと溶鋼およ びモールドパウダーの濡れ性の変化が原因で二液界面がノ ズル壁に沿って上下に振動し，ノズルを溶損することが明 らかにされた ${ }^{24,25)}$ 。モールドパウダーと $\mathrm{Al}_{2} \mathrm{O}_{3}$ および溶鋼

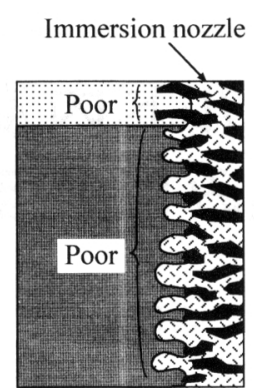

(a)

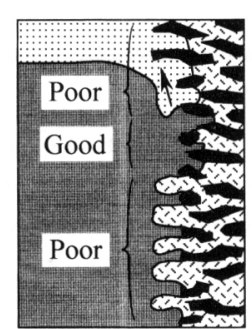

(c)

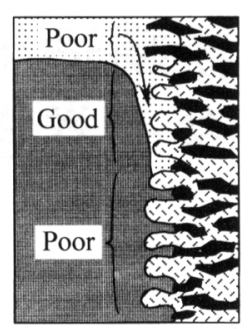

(b)

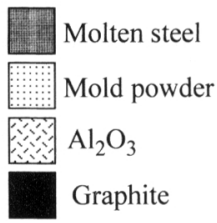

Good: Wetted Poor: Poorly wetted
Fig. 2. Movement of mold powder due to change in wettability on the surface of immersion nozzle.

とグラファイトは濡机性が良い。そのために，何らかの理 由でモールドパウダーが $\mathrm{Al}_{2} \mathrm{O}_{3}$ リッチ層に接触すると, 濡 れ性が良いためにモールドパウダーはノズル表面に沿って 降下する (Fig. 2(b))。年の後, $\mathrm{Al}_{2} \mathrm{O}_{3}$ がモールドパウダーに 溶解してグラファイトリッチ層となると，モールドパウ ダーとの濡れ性が悪く溶鋼との濡れ性が良くなることか ら, Fig. 2(c) に示すように溶鋼が浸入してモールドパウ ダーは上昇する。このように，モールドパウダーと溶鋼の 二層界面近傍のノズル表面では液体との濡机性が時々刻々 変化するために，二層界面が上下に振動し，その結果とし てノズルの溶損が進行する。

\section{$2 \cdot 2$ ノズル表面に圧力差による流れが生じた場合}

溶鋼の急激な片流れによって生じた圧力差が駆動力と なってモールドパウダーが降下しはじめると, Fig. 2(b) に 示した状態が持続することになる。したがって，溶鋼と浸 漬ノズルの濡れ性は悪く, モールドパウダーと浸漬ノズル との濡れ性は良い状態のままになる。すなわち, モールド パウダーの降下は，溶鋼と浸漬ノズルとの濡れ性が良い場 合よりも助長されると考えられる。本研究では, この推測 の妥当性を確認するために，溶鋼のモデルとして食塩水を， モールドパウダーのモデルとして種々の動粘度のシリコン オイルを用いるが，浸漬ノズルを模擬したアルミニウム製 円柱の表面に撥水剤を塗布することによって円柱と食塩水 の濡れ性を悪くし，ノズル表面の濡れ性がモールドパウ ダーの降下に及ぼす影響を調査した。なお，液体の速度は 粒子画像流速計 (PIV) を用いて測定した。本研究では, 可 視化されたトレーサー粒子の移動画像（アナログ信号）を 


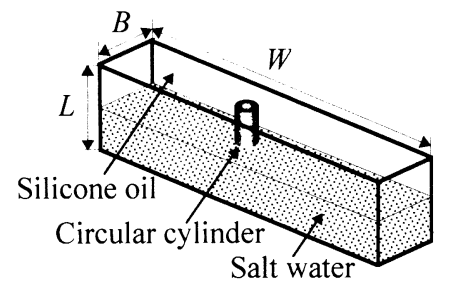

(a) Vessel

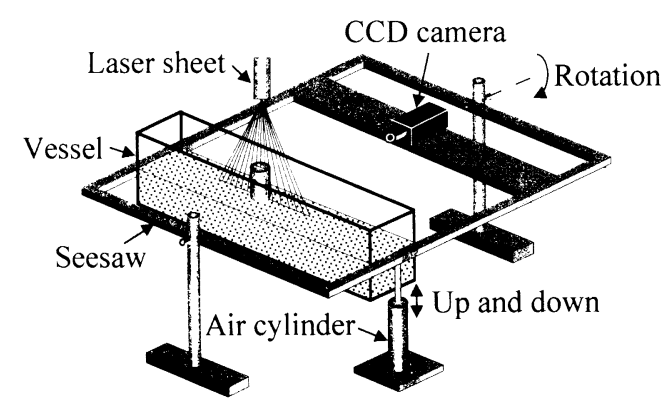

(b) Bird's-eye view

Fig. 3. Schematic illustration of experimental apparatus.

画像ボードでAD変換してパーソナルコンピューターに取 り込み，相互相関法により画像解析を行うことで液体の流 速を測定するシステムを用いた ${ }^{26)}$

\section{3. 実験装置と方法}

Fig. 3 に実験装置の概要を示す。Fig. 3(a) に示した容器 は，実機における鋳型の約 $1 / 2$ サイズの幅 $W=1.000 \mathrm{~m}$ ，厚 み $B=0.100 \mathrm{~m}$, 長さ $L=0.200 \mathrm{~m}$ の透明アクリル製容器であ る。容器の中心には，浸漬ノズルに見たてたアルミニゥム 製円柱を容器上壁と重直に設置した。アルミニウム製円柱 の直径 $D$ は， $D=0.010,0.020,0.030,0.040 \mathrm{~m}$ の種類である。 円柱による流路のブロッケージファクター $D / B$ は $0.1 \sim 0.4$ となる。容器中には, 容器の長さ $L$ とシリコンオイル層の 厚さ $H_{1}$ の比 $H_{1} / L$ が $0.15,0.25,0.50$ となるように食塩水とシ リコンオイルを満たした。また，円柱の表面には食塩水と の濡机性を悪くするために撥水剤を塗布した。撥水剤を塗 布した円柱と食塩水の接触角は $120 \mathrm{deg}$.であり，円柱とシ リコンオイルの接触角はシリコンオイルの動粘度に関わら ずほぼ 0 deg.であった。本実験では，撥水剤を塗布した円 柱を濡れ性が覀い円柱，撥水㘊を塗布していない元の円柱 を濡机性が良い川柱と呼ぶ。液体の温度はいずれも $298 \mathrm{~K}$ である。物性值を Table 1 に示す。ここで $v$ は動粘度， $\rho$ は 密度， $\sigma_{12}$ は界面張力，添字 1,2 はそれぞれ上層と下層の 液体を表す。またSilicone oil 2 は, 動粘度が $2.0 \mathrm{~mm}^{2} / \mathrm{s}$ のシ リコンオイルを表しており，他の液体についても同意であ る。

液体中には,PIVを用いた画像解析のために粒径
Table 1. Physical properties of liquids (298K).

\begin{tabular}{|l|c|c|c|}
\hline \multicolumn{1}{|c|}{ Liquid } & $\begin{array}{c}\text { Kinematic } \\
\text { viscosity } \\
v_{1}, v_{2} \\
\left(\mathrm{~mm}^{2} / \mathrm{s}, \mathrm{cSt}\right)\end{array}$ & $\begin{array}{c}\text { Density } \\
\rho_{1}, \rho_{2} \\
\left(\mathrm{~kg} / \mathrm{m}^{3}\right)\end{array}$ & $\begin{array}{c}\text { Interfacial } \\
\text { tension } \\
\sigma_{12} \\
(\mathrm{mN} / \mathrm{m})\end{array}$ \\
\hline Salt water & 1.0 & 1013 & \\
\hline Silicone oil 2 & 2.0 & 873 & 52.7 \\
\hline Silicone oil 10 & 10 & 935 & 52.7 \\
\hline Silicone oil 50 & 50 & 960 & 52.7 \\
\hline Silicone oil 100 & 100 & 965 & 53.0 \\
\hline
\end{tabular}

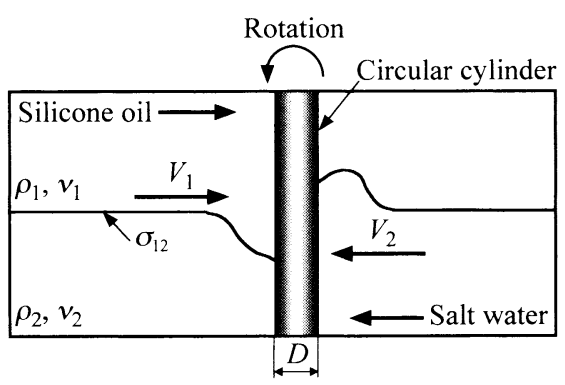

Fig. 4. Symbols used in this study.

75 150 $\mu \mathrm{m}$ のトレーサー粒子を混入してある。食塩水中に 混入した粒子はスチレンージビニルベンゼン共重合体製で あり，シリコンオイル中に混入した粒子はポリエチレン製 である。粒子の密度は液体と同密度になるように調整して いるが，今回 Silicone oil 2 と同密度のトレーサー粒子が見 当たらなかったために, Silicone oil 2のみに対してはト レーサー粒子を混入していない。しかし前報17)で，Silicone oil 20液層中に打ける主流と垂直な方向への速度勾 配はほとんどなく，連続の式によりシリコンオイルの速度 を算出できることが分かっている。したがって，本研究に おいても Silicone oil 2 の速度は同様にして求めた。

トレーサー粒子の動きを可視化するために，幅 $2.0 \mathrm{~mm}$ のレーザーシート光を用いて容器の縦断面を照射した。卜 レーサー粒子が液体中に中立浮遊状態で停止していること を確認した後，エアシリンダーにより容器を水平から傾斜 角度 $\theta=10,20 \mathrm{deg}$., 回転速度 $\Omega_{r}=2.7,3.8,18.7 \mathrm{deg} . / \mathrm{s}$ で傾斜 後, 停止させた。可視化された粒子を撮影するために， CCDカメラ (30 frames/s) を用いた。CCDカメラからパー ソナルコンピューターに取り込まれた際の画素数は $512 \times 480$ である。Fig. 4 は容器縦断面の模式図であり， あ わせて本研究で用いた主な記号を記入している。

\section{4. 実験結果と考察}

\section{$4 \cdot 1$ 円柱周囲における二液界面の变形}

Fig. 5は, 容器側面から観察した容器傾斜前の円柱周囲 における二液界面の形状の一例を表している。円柱表面に 撥水剤を塗布しないとき (Fig. 5(a)), 二液界面は円柱表面 とほぼ垂直であるが，撥水剤を塗布したとき食塩水側の接 


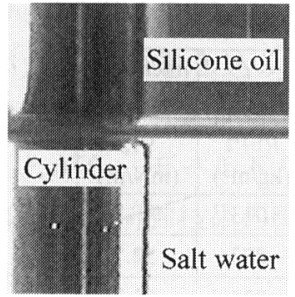

Photograph

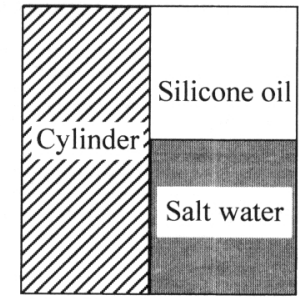

Schematic (a) Wetted cylinder

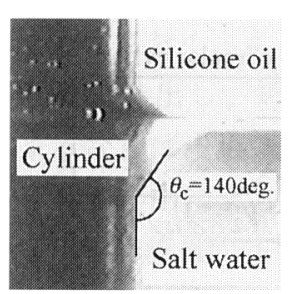

Photograph

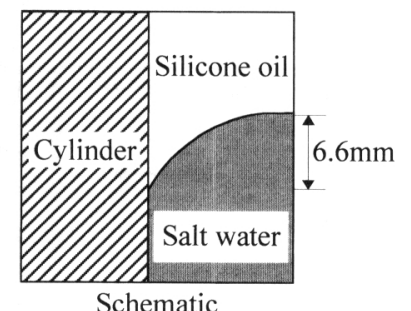

Schematic (b) Poorly wetted cylinder

Fig. 5. Configuration of interface around circular cylinder before inclination of vessel [Silicone oil 100, $D=0.03 \mathrm{~m}]$.

Table 2. Contact angle between circular cylinder coated with repellent and salt water/silicone oil interface.

\begin{tabular}{|l|l|}
\hline & $\theta_{\mathrm{c}}$ \\
\hline Silicone oil 2 & $143^{\circ}$ \\
\hline Silicone oil 10 & $144^{\circ}$ \\
\hline Silicone oil 50 & $143^{\circ}$ \\
\hline Silicone oil 100 & $140^{\circ}$ \\
\hline
\end{tabular}

触角 $\theta_{c}$ は $90 \mathrm{deg}$.より大きく Fig. $5(\mathrm{~b})$ では $140 \mathrm{deg}$.となった。 ほかのシリコンオイルに対して観察された $\theta_{c}$ の值を Table 2 に示す。なお, シリコンオイルの初期降下量は $6 \mathrm{~mm}$ 程 度であり, 本実験条件下では圧力差によって生じる降下量 に比べて無視できる。

容器の傾斜後, 円柱前方表面では圧力が高くなり, 後方 表面では低くなることから二液界面は Fig. 4 に模式的に示 すように上下に移動し，激しい巻き込々現象が観察された。 円柱の左側に扔いて二液界面が降下するとき，濡れ性の良 い場合は円柱から離れた部分において二液界面が最も降下 したのに対して，濡栍が悪い場合は円柱表面に扔いて二 液界面が最も降下していた (Fig. 6)。これは，濡机性が悪 い場合には円柱が食塩水をはじくために濡机性が良い場合 と比べてシリコンオイルの降下に刘する流動抵抗が小さく なることが原因であると考光られる。また，円柱の右側で も圧力差によって二液界面が上昇してシリコンオイルの巻 き込々が発生するが，巻き込まれたシリコンオイルは梁く 降下せずに，浮力によってすぐにシリコンオイル層に戻る

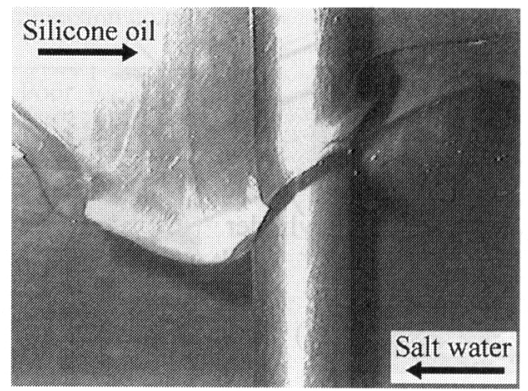

(a) Wetted cylinder

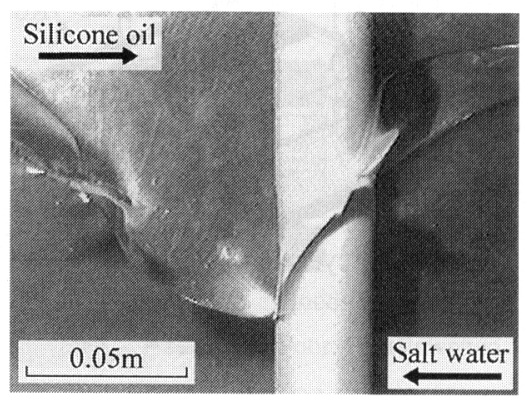

(b) Poorly wetted cylinder

Fig. 6. Deformation of interface around circular cylinder [Silicone oil $100, D=0.03 \mathrm{~m}, H_{1}=0.1 \mathrm{~m}, \Omega_{r}=3.8$ deg./s, $\theta=20 \mathrm{deg}$.$] .$
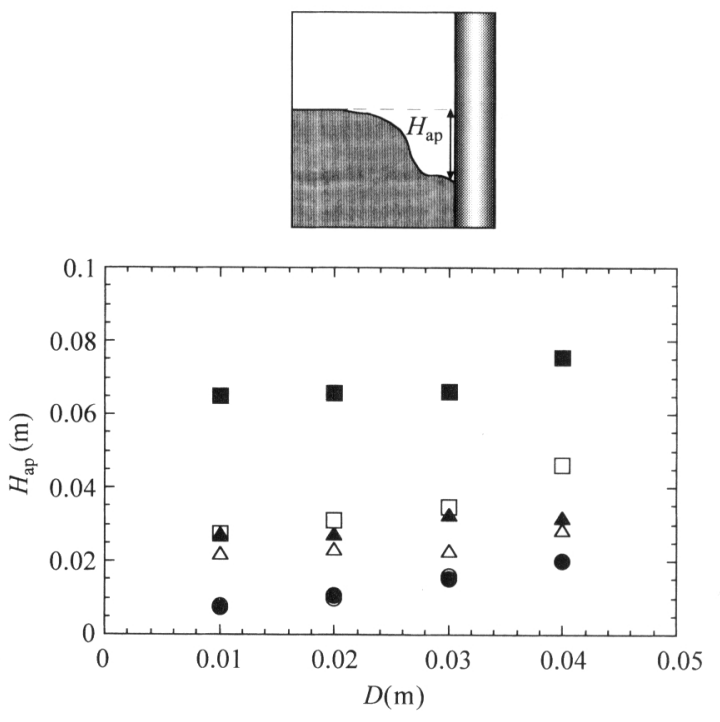

O $\Omega_{\mathrm{r}}=2.7 \mathrm{deg} . / \mathrm{s}, \theta=10 \mathrm{deg} . \quad \Omega_{\mathrm{r}}=2.7 \mathrm{deg} . / \mathrm{s}, \theta=20 \mathrm{deg}$. $\Delta \Omega_{\mathrm{r}}=3.8 \mathrm{deg} . / \mathrm{s}, \theta=10 \mathrm{deg} . \quad \Delta \Omega_{\mathrm{r}}=3.8 \mathrm{deg} . / \mathrm{s}, \theta=20 \mathrm{deg}$. $\square \Omega_{\mathrm{r}}=18.7 \mathrm{deg} . / \mathrm{s}, \theta=10 \mathrm{deg} . \mathbf{\Omega} \Omega_{\mathrm{r}}=18.7 \mathrm{deg} . / \mathrm{s}, \theta=20 \mathrm{deg}$.

Fig. 7. Maximum descending distance of interface $H_{a p}$ [Silicone oil 2].

ことから左側の巻き込みに比べると重要ではない17)。

\section{$4 \cdot 2$ 二液界面の最大降下距離 $H_{a p}$}

円柱への食塩水の近寄り速度が一定值に達したのち，二 液界面が濡れ性の悪い円柱後方表面に沿って最も降下した 距離 $H_{a p}$ の一例を Fig. 7 に示す。前報 (17) では円柱表面に沿 う二液界面の最大降下距離を $H_{a}$ と表したが，本報では濡 


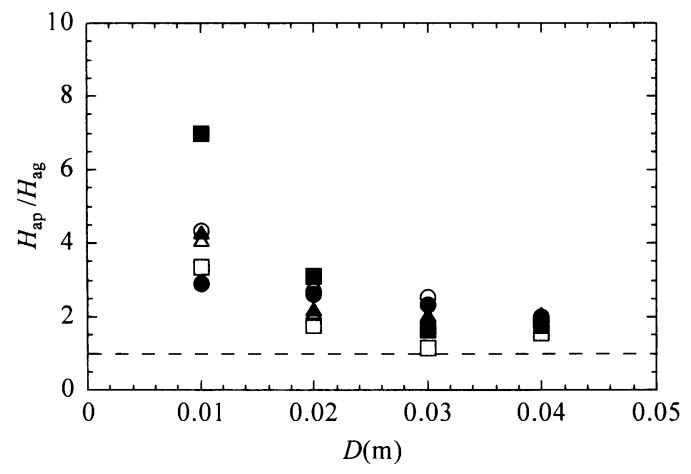

$\triangle \Omega_{\mathrm{r}}=2.7 \mathrm{deg} . / \mathrm{s}, \theta=10 \mathrm{deg} . \quad \bullet \Omega_{\mathrm{r}}=2.7 \mathrm{deg} . / \mathrm{s}, \theta=20 \mathrm{deg}$.
$\Delta \Omega_{\mathrm{r}}=3.8 \mathrm{deg} . / \mathrm{s}, \theta=10 \mathrm{deg} . \Delta \Omega_{\mathrm{r}}=3.8 \mathrm{deg} . / \mathrm{s}, \theta=20 \mathrm{deg}$.
$\square \Omega_{\mathrm{r}}=18.7 \mathrm{deg} . / \mathrm{s}, \theta=10 \mathrm{deg} . \backsim \Omega_{\mathrm{r}}=18.7 \mathrm{deg} . / \mathrm{s}, \theta=20 \mathrm{deg}$.

Fig. 8. Comparison between $H_{a p}$ and $H_{a g}$ [Silicone oil 2].

れ性が良い場合にはさらに添字 $\mathrm{g}$ をけて $H_{a g}$, 濡れ性が 悪い場合には添字 $\mathrm{p}$ をけて $H_{a p}$ と表している。 $H_{a p}$ は円柱 の直径 $D$, 容器の回転速度 $\Omega_{r}$, 容器の傾斜角度 $\theta$ に依存し ている。これは, 容器の回転速度 $\Omega_{r}$, 容器の傾斜角度 $\theta$ が大きくなると液体の速度が大きくなるために円柱周辺で の圧力変化が大きくなり, 円柱の直径 $D$ が大きいほど圧力 変化が生じる領域が広くなるためである。なお, Fig. 5 に 示したように円柱と二液界面の接点の初期位置は円柱表面 の濡れ性の違いにより異なるが，実機に適用する場合を想 定して円柱から離れた水平な界面を基準に二液界面の降下 距離を測定した。

Fig. 8 に示すように, 濡れ性が悪い場合の $H_{a p}$ の方が需 れ性の良い場合の值 $H_{a g}$ よりも大きいことがわかる。この 四から, 円柱の直径Dの小さい方が濡れ性の影響を強く受 けるように見えるが，そうではなく円柱の直径 $D$ が小さい ほど流路のブロッケージファクターが小さくなって液体の 円柱への近寄り速度が大きくなるためである。

\section{$4 \cdot 3$ 二液界面の降下に対する上限臨界值 $H_{\mathrm{ap}, \mathrm{ul}}$}

前報 17) では，浸漬ノズルを片流れが一定速度で急に横 切った場合の二液界面近傍における円柱のよどみ点におけ る圧力, 重力, 浮力のバランスから式 (1) に示す二液界 面の降下距離 $H_{a g}$ を導いた。

$$
H_{a g}=\frac{\rho_{1} V_{1}^{2}+2.5 \rho_{2} V_{2}^{2}}{2 g\left(\rho_{2}-\rho_{1}\right)}
$$

ここで $g$ は重力加速度を表す。濡れ性が良い場合について は，二液界面が最も降下した位置から円柱壁面までの水平 距離 $L_{b}$ に対する実験式 (2) を導いているが ${ }^{17)}$, この $L_{b}$ を 濡れ性の悪い場合にも代表長さとして用いる。

$$
L_{b}=D\left[\frac{\rho_{2} V_{2}^{2}}{g D\left(\rho_{2}-\rho_{1}\right)}\right]^{0.7}
$$

$H_{a p}$ の測定值と $H_{a g}$ の計算值の比 $H_{a p, \text { mea }} / H_{a g}$ と $D / L_{b}$ の関係は

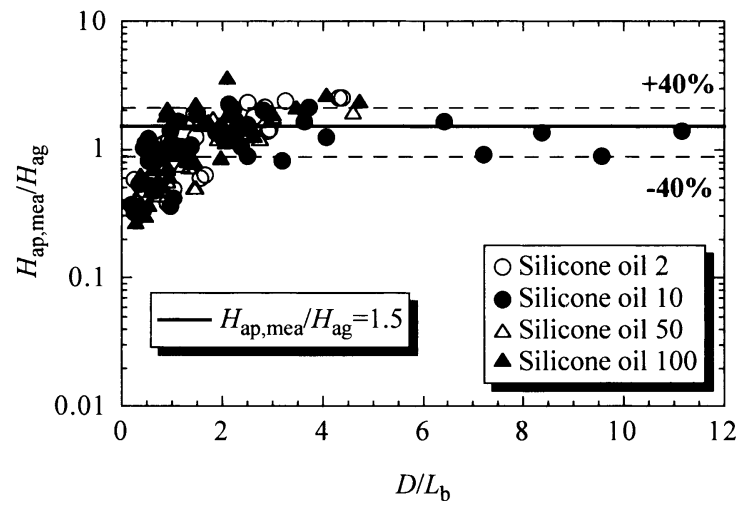

Fig. 9. Relation between $H_{a p \text {, mea }} / H_{a g}$ and $\mathrm{D} / L_{b}$.

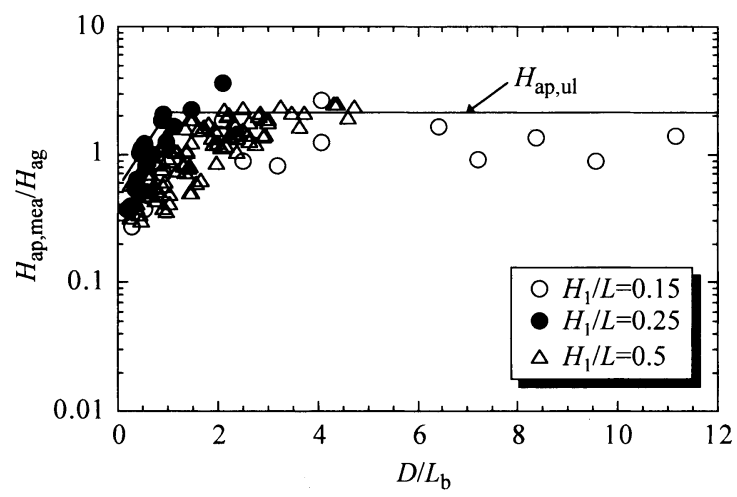

Fig. 10. Upper limit of descending distance in the case of poorly wetted cylinder, $H_{a p, \mathrm{ul}}$.

Fig. 9のようになる。

$D / L_{b} \geqq 2.0$ において,$H_{a p, \mathrm{mea}} / H_{a g}$ は次式により $\pm 40 \%$ の偏 差で近似できる。

$$
H_{a p, \text { mea }}=1.5 H_{a g}
$$

$D / L_{b}<2.0$ において式 (3) が適用できないのは, 円柱の直 径が小さいと円柱の後方で二液界面の降下する領域が狭く なり，界面の降下に対する流動抵抗が大きくなるためであ ると考えられる。また，この図から， $H_{a p}$ に対する液体の 動粘度の影響は小さいといえる。

Fig. 9 において, 前報 ${ }^{17)}$ と同様に各横軸の值に対する測 定值の最大值を Fig.10に示すように直線近似し，これを二 液界面の降下に対する上限臨界值 $H_{a p, \mathrm{ul}}$ と表せば, $D / L_{b} \geqq 1.0$ において, $H_{a p, \mathrm{ul}}$ は式 ( 3 ) の $+40 \%$ の值となるこ とから

$$
H_{a p, \mathrm{ul}}=2.1 H_{a g}
$$

と表される。一方,$D / L_{b}<1.0$ において,$H_{a p, \text { ul }}$ は

$$
H_{a p, \mathrm{ul}}=0.63 H_{a g} \exp \left(1.2 D / L_{b}\right)
$$

となる。なお，本実験条件下では， $H_{a p}$ に対するシリコン オイル層の厚さの影響はほとんどない。 


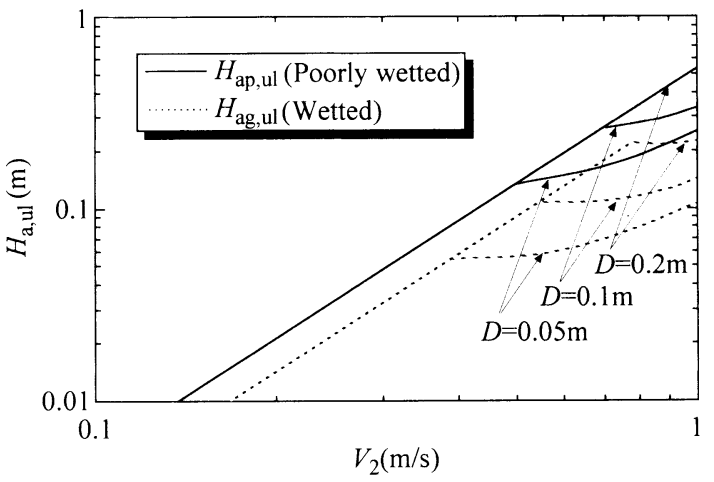

Fig. 11. Application of $H_{a, \text { ul }}$ to real process.

\section{$4 \cdot 4$ 実機への適用}

水上ら ${ }^{20)}$ は，実機でカルマン渦流速計により溶鋼のメ ニスカス流速を測定し, 鋳造速度が $5 \mathrm{~m} / \mathrm{min}$ の高速連鋳に 打いて，電磁ブレーキをかけた状態でのメニスカス流速は 約 $0.3 \mathrm{~m} / \mathrm{s}$ であると報告している。したがって電磁ブレー キをかけないときのメニスカスの瞬間流速が $0.3 \mathrm{~m} / \mathrm{s} よ り$ 大きいことは十分に考えられる。さらに片流れが生じた場 合には，メニスカス流速はさらに大きくなるであろう。し かしながら，現在のところ具体的な測定值が見当たらない ので, 本研究では溶鋼のメニスカス流速を $V_{2}=0.1 \sim 1.0 \mathrm{~m} / \mathrm{s}$ と大きく見積った。さらにモールドパウダーは静止してい ると仮定して速度を $V_{1}=0 \mathrm{~m} / \mathrm{s}$ とする。モールドパウダー の密度は $\rho_{1}=3500 \mathrm{~kg} / \mathrm{m}^{3}$, 溶鋼の密度は $\rho_{2}=7000 \mathrm{~kg} / \mathrm{m}^{3}$ と仮 定する。式 ( 1 ), ( 2 ), (4), ( 5 ) を基にして実機内の $H_{a p, \mathrm{ul}}$ を 計算し, 浸漬ノズル外径 $D$ をパラメータとして Fig.11に実 線で表した。罒中の破線は，前報 ${ }^{17)} に$ 示した濡れ性が良 い場合の $H_{a g, \mathrm{ul}}$ を表している。溶鋼の速度 $V_{2}$ と浸漬ノズル 外徍Dの増加につれて，モールドパウダーは浸漬ノズルの 濡れ性の悪い方が良い場合よりも 1.5 倍ほど降下すること がわかる。

例えば, $V_{2}=0.6 \mathrm{~m} / \mathrm{s}, D=0.1 \mathrm{~m}$ のとき, $H_{a p, \mathrm{ul}}=0.19 \mathrm{~m}$ とな り，この值は実機における浸漬ノズルの浸漬深さに相当し ている。したがって，浸漬ノズルに沿って降下したモール ドパウダーは，浸漬ノズル吐出孔からの溶鋼流に吸い込ま れて細かく分断され，溶鋼中へ分散する可能性は十分にあ ると考えられる。

\section{$4 \cdot 5$ 浸清ノズルの濡れ性とモールドパウダーの降下に対 する上限臨界值との関係}

本実験により，2章で述べた最大降下距離に及ぼす濡れ 性の効果が立証された。そこで，ここでは濡れ性の影響を もう少し詳しく整理しておく。压力差によってモールドパ ウダーが降下する前の初期界面状態を Fig.12(a) に示すよ うに水平界面であると仮定する。浸漬ノズルを右から左へ 横切る流れが発生すると, Fig.12(b) のようにノズル周辺の 圧力差によってノズル左側のモールドパウダーは降下す る。このとき, Fig.12(c) に示すようにモールドパウダーと

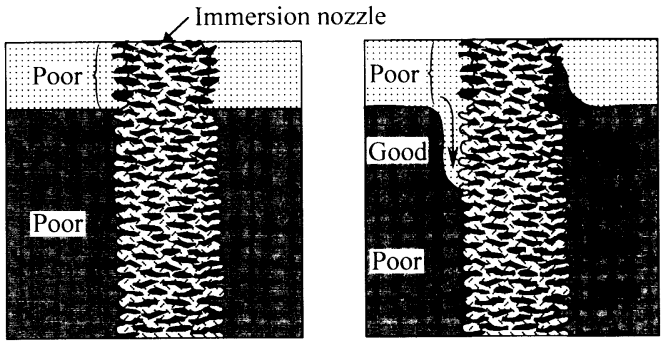

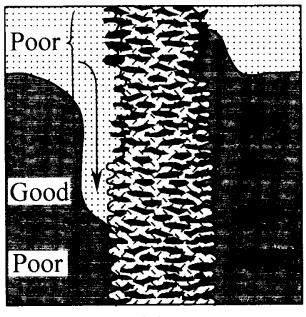

(c) (b)

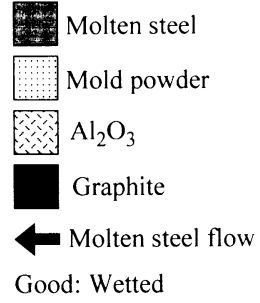

Poor: Poorly wetted
Fig. 12. Descent of mold powder along surface of immersion nozzle with wettability difference.

接触した $\mathrm{Al}_{2} \mathrm{O}_{3}$ は上から徐々に溶解し，グラファイトリッ チ層となってモールドパウダーと濡れ性が悪くなる。しか しながら, 圧力差によってモールドパウダーが降下しつづ けるかぎり，降下部先端は常に $\mathrm{Al}_{2} \mathrm{O}_{3}$ リッチ層と接触し降 下を促進すると考えられる。このことの妥当性は佐藤ら 27) の実験結果からも支持される。佐藤らは, 微小重力環境に おいて濡れ性の公配が存在する板上では，液滴が濡れ性の 悪い領域から濡れ性の良い領域へ移動することを報告して いる。このように，実機における浸漬ノズルとモールドパ ウダーの濡机性は良くなり，浸漬ノズルと溶鋼との濡れ性 は悪くなるが，これは本実験でモデル化した状態と全く同 じである。したがって実機においても式 (4), ( 5 ) が適用 できると考えられる。しかしながら，モールドパウダーの 物性值は $\mathrm{Al}_{2} \mathrm{O}_{3}$ の溶解により変化する。本研究では，モー ルドパウダーの物性值の変化が二液界面の降下に及ぼす影 響を考慮していない。この点については今後の課題とした is

また，Fig. 2(c) のように，圧力差によってモールドパウ ダーが降下する直前の初期状態に打いて，モールドパウ ダ一層直下の表面が溶鋼と濡机性が良い場合も考えられ る。このとき, 溶鋼と濡れ性の良い部分の距離は $0.01 \mathrm{~m}$ ほ どであり ${ }^{24)}$, Fig. 11 より, $H_{a g . \mathrm{ul}}=0.01 \mathrm{~m}$ のとき $V_{2}=0.17 \mathrm{~m} / \mathrm{s}$ となる。したがって $V_{2}>0.17 \mathrm{~m} / \mathrm{s}$ であれば，モールドパウ ダーの降下に対する濡れ性の初期条件の影響を無視するこ とができると考えられる。

なお，本研究に打いて食塭水と撥水戍を塗布したアルミ ニウム製円柱の接触角は $120 \mathrm{deg}$.であるのに対して実機の 溶鋼と $\mathrm{Al}_{2} \mathrm{O}_{3}$ の接触角は134〜157 deg.であることから，接 触角をパラメータとした $H_{a p, \text { ul }}$ の評価が今後必要であると 考えられる。また，薄肉スラブ連続鋳造では長方形断面の 
浸漬ノズル ${ }^{28)}$ が使用されることもあるために，ノズルの 断面形状が $H_{a p, \text { ul }}$ に及ぼす影響を無視することはできない。 さらに, $H_{a p, \text { ul }}$ には液体の界面張力が影響し, 浸漬ノズル

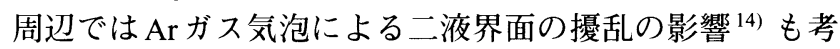
えられるので詳細については今後の課題としたい。

\section{5. 結言}

連続鋳造鋳型内において, 浸漬ノズル表面壁での圧力差 によるモールドパウダーの巻き込み現象に及ぼす浸漬ノズ ル表面の需れ性の影響を食塩水とシリコンオイルを用いた 水モデル実験により調査した。得られた主な成果は以下の とおりである。

（1） 円柱表面の濡れ性が悪い場合は, 円柱が食塩水を はじいてシリコンオイルの降下に対する流動抵抗が小さく なるために，シリコンオイルが円柱表面において最も降下 していた。それに対して濡れ性が良い場合は，円柱から離 れた位置においてシリコンオイルは最も降下していた。

（2）濡れ性の悪い浸漬ノズル表面に沿う二液界面の最 大降下距離 $H_{a p}$ は, $D / L_{b} \geqq 2.0$ において, 以下の式により 土40\%の偏差で近似できる。

$$
H_{a p}=1.5 H_{a g}
$$

（３）濡れ性の悪い浸漬ノズル表面に沿う二液界面の降 下に対する上限臨界值 $H_{a p, \mathrm{ul}}$ に関して，以下に示す実験式 を導いた。

$$
\begin{array}{ll}
H_{a p, \mathrm{ul}}=2.1 H_{a g} & \left(D / L_{b} \geqq 1.0\right) \\
H_{a p, \mathrm{ul}}=0.63 H_{a g} \exp \left(1.2 D / L_{b}\right) & \left(D / L_{b}<1.0\right)
\end{array}
$$

これらの值は，濡れ性の良い浸漬ノズル表面における值 $H_{a g, \mathrm{ul}}$ よりも約 1.5 倍大きい。

\section{記 号}

$\begin{array}{llr}B & : \text { 容器の厚み } & (\mathrm{m}) \\ D & : \text { 円柱の直径 } & (\mathrm{m}) \\ g & : \text { 重力加速度 } & \left(\mathrm{m} / \mathrm{s}^{2}\right) \\ H_{1} & : \text { シリコンオイル層の厚さ } & (\mathrm{m}) \\ H_{a g} & : \text { 濡れ性の良い円柱後方壁面に沿う二液界面の最大降下距離 } \\ & & (\mathrm{m}) \\ H_{a p} & : \text { 濡れ性の悪い円柱後方壁面に沿う二液界面の最大降下距離 } \\ & & (\mathrm{m}) \\ L & : \text { 容器の長さ } & (\mathrm{m}) \\ L_{b} & : \text { 液界面が最も降下した地点から円柱壁面までの距離 } & (\mathrm{m}) \\ V & : \text { 液体の速度 } & (\mathrm{m} / \mathrm{s}) \\ W & : \text { 容器の幅 } & (\mathrm{m}) \\ v & : \text { 液体の動粘度 } & (\mathrm{mm} / \mathrm{s})\end{array}$

$\theta \quad:$ 容器の傾斜角度

$\theta_{c} \quad$ : 円柱と二液界面の接触角度

$\rho$ : 液体の密度

$\sigma:$ : 液体の表面張力

$\Omega_{\mathrm{r}}:$ 容器の回転速度

添字

1 : 容器中の上の層 (モールドパウダー層)

2 : 容器中の下の層 (溶鋼層)

mea：測定值

ul ：上限臨界值

\section{文献}

1 ) 浅井滋生：第 $100 \cdot 101$ 回西山記念技術講座，日本鉄鋼協会編， 東京, (1984), 65 .

2 ) 小舞忠信, 佐伯 毅, 堤 直人:日本学術振興会製鋼第 19 委 員会第 3 分科会凝固現象協議会資料 No. 19 委-10801 凝固-426, (1987).

3 ) N.Kasai, M.Kawasaki, K.Hanazaki and T.Sakashita: CAMP-ISIJ, 3 (1990), 1114

4 ) T.Yamasaki, H.Hasegawa, T.Fuji and T.Imoto: CAMP-ISIJ, 10 (1997), 236.

5 ) D.Gupta and A.K.Lahiri: Ironmaking Steelmaking, 23 (1996), 361.

6 ) T.Katai, Y.Otsuka, K.Shigematsu, T.Imoto and H.Iiboshi: CAMPISIJ, 11 (1998), 861

7 ) J.Kubota, K.Okimoto, Y.Oka, T.Masaoka and M.Suzuki: CAMP-ISIJ, 3 (1990), 1098.

8 ) M.Iguchi, J.Yoshida, T.Shimizu and Y.Mizuno: ISIJ Int., 40 (2000), 685.

$9)$ H.Tanaka, H.Kuwatori and R.Nishihara: Tetsu-to-Hagané, 78 (1992), 761.

10) Y.Yamaoka, M.Suzuki and K.Murakami: CAMP-ISIJ, 6 (1993), 279.

11) H.E.Oinglin: ISIJ Int., 33 (1993), 343.

12) K.Watanabe, M.Suzuki and M.Nakata: CAMP-ISIJ, 14 (2001), 2.

13) M.Iguchi, Y.Sumida, R.Okada and Z.Morita: Tetsu-to-Hagané, 79 (1993), 569

14) Z.Wang, K.Mukai, Z.Ma, M.Nishi, H.Tsukamoto and F.Shi: ISIJ Int., 39 (1999), 795.

15) J.Yoshida, S.Yamashita and M.Iguchi: CAMP-ISIJ, 13 (2000), 973.

16) T.Inada, Y.Nishihara, H.Tanaka, S.Matsui, M.Sakaki, S.Sakaguchi and N. Zeze: CAMP-ISIJ, 9 (1996), 196.

17) J.Yoshida, M.Iguchi and S.Yokoya: Tetsu-to-Hagané, 87 (2001), 529.

18) Z.Wang, K.Mukai and D.Izu: ISIJ Int., 39 (1999), 154.

19) T.Okimura, Y.Nakajima, K.Shimada, J.Ikeda and M.Tawara: CAMPISIJ, 9 (1996), 213.

20) H.Mizukami, M.Hanao, S.Hiraki, M.Kawamoto, T.Watanabe, A.Hayashi and M.Iguchi: Tetsu-to-Hagané, 86 (2000), 265.

21) J.Kubota, N.Kubo, M.Suzuki, T.Ishii, R.Nishimachi and N.Aramaki: Tetsu-to-Hagané, 86 (2000), 271.

22) T.Hiraoka, T.Ohashi, H.Matsunaga and T.Hiromoto: Seitetsu Kenkyu, 294 (1978), 79.

23) K.Ichikawa and W.Lin: CAMP-ISIJ, 13 (2000), 170.

24) K.Mukai, J.M.Toguri and J.Yoshitomi: Can. Metall. Q., 25 (1986), 265

25) K.Mukai: ISIJ Int., 32 (1992), 19.

26) T.Tsuda, T.Namieno, T.Saga and T.Kobayashi: Shinnittetsu Giho, 359 (1996), 32.

27) M.Sato, K.Araki, T.Matsuura and A.Endo: Space Utilization Res., 16 (2000), 261

28) T.Kanazawa, K.Marukawa, K.Nakai, T.Yamada and K.Nakajima: Sumitomo Met., 45 (1993), 117. 